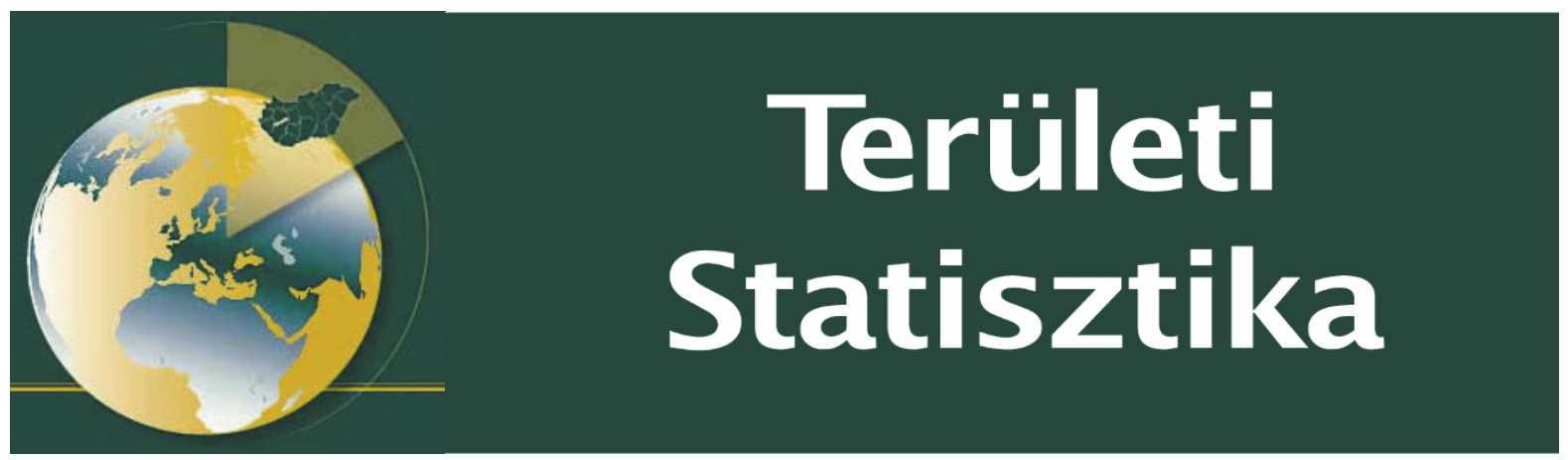

Közzététel: 2019. február 12.

A tanulmány címe:

A budapesti várostérség fogyasztási alapú ökológiai lábnyomának változása 2003 és 2013 között

Szerzők:

Harangozó Gábor Budapesti Corvinus Egyetem Gazdálkodástudományi Kar Logisztika és Ellátási Lánc Menedzsment Tanszék, E-mail: gabor.harangozo@uni-corvinus.hu

Kovács Zoltán MTA CSFK Földrajztudományi Intézet Szegedi Tudományegyetem Gazdaságés Társadalomföldrajz Tanszék, E-mail: zkovacs@iif.hu

Kondor Attila Csaba MTA CSFK Földrajztudományi Intézet, E-mail: kondor.attila@csfk.mta.hu

Szabó Balázs MTA CSFK Földrajztudományi Intézet, E-mail: szbazs@gmail.com

https://doi.org/10.15196/TS590105

Az alábbi feltételek érvényesek minden, a Központi Statisztikai Hivatal (a továbbiakban: KSH) Területi Statisztika c. folyóiratában (a továbbiakban: Folyóirat) megjelenó tanulmányra. Felhasználó a tanulmány, vagy annak részei felhasználásával egyidejüleg tudomásul veszi a jelen dokumentumban foglalt felhasználási feltételeket, és azokat magára nézve kötelezönek fogadja el. Tudomásul veszi, hogy a jelen feltételek megszegéséból eredó valamennyi kárért felelösséggel tartozik.

1) A jogszabályi tartalom kivételével a tanulmányok a szerzői jogról szóló 1999. évi LXXVI. törvény (Szjt.) szerint szerzői műnek minősülnek. A szerzői jog jogosultja a KSH.

2) A KSH földrajzi és időbeli korlátozás nélküli, nem kizárólagos, nem átadható, térítésmentes felhasználási jogot biztosít a Felhasználó részére a tanulmány vonatkozásában. 3) A felhasználási jog keretében a Felhasználó jogosult a tanulmány:

a) oktatási és kutatási célú felhasználására (nyilvánosságra hozatalára és továbbítására a

4. pontban foglalt kivétellel) a Folyóirat és a szerző(k) feltüntetésével;

b) tartalmáról összefoglaló készítésére az írott és az elektronikus médiában a Folyóirat

és a szerző(k) feltüntetésével;

c) részletének idézésére - az átvevő mű jellege és célja által indokolt terjedelemben és az eredetihez híven - a forrás, valamint az ott megjelölt szerző $(\mathrm{k})$ megnevezésével.

4) A Felhasználó nem jogosult a tanulmány továbbértékesítésére, haszonszerzési célú felhasználására. Ez a korlátozás nem érinti a tanulmány felhasználásával előállított, de az Szjt. szerint önálló szerzői műnek minősülő mű ilyen célú felhasználását.

5) A tanulmány átdolgozása, újra publikálása tilos.

6) A 3. a)-c.) pontban foglaltak alapján a Folyóiratot és a szerző(ke)t az alábbiak szerint kell feltüntetni:

„Forrás: Területi Statisztika c. folyóirat 59. évfolyam 1. számában megjelent, Harangozó Gábor - Kovács Zoltán Kondor Attila Csaba - Szabó Balázs által irt A budapesti várostérség fogyasztási alapú ökológiai lábnyomának változása 2003 és 2013 kö̈ött"

7) A Folyóiratban megjelenő tanulmányok kutatói véleményeket tükröznek, amelyek nem esnek szükségképpen egybe a $\mathrm{KSH}$, vagy a szerzők által képviselt intézmények hivatalos álláspontjával. 


\section{A budapesti várostérség fogyasztási alapú ökológiai lábnyomának változása 2003 és 2013 között}

\section{Changes in the household consumption-based ecological foot- print of Budapest metropolitan region between 2003 and 2013}

Harangozó Gábor

Budapesti Corvinus Egyetem

Gazdálkodástudományi Kar

Logisztika és Ellátási Lánc

Menedzsment Tanszék

E-mail:

gabor.harangozo@uni-corvinus.hu

Kovács Zoltán MTA CSFK

Földrajztudományi Intézet

Szegedi Tudományegyetem Gazdaság- és Társadalomföldrajz

Tanszék

E-mail:

zkovacs@iif.hu

Kondor Attila Csaba

MTA CSFK

Földrajztudományi Intézet

E-mail:

kondor.attila@csfk.mta.hu

\section{Szabó Balázs}

MTA CSFK

Földrajztudományi Intézet

E-mail:

szbazs@gmail.com

Kulcsszavak:

szuburbanizáció,

fenntartható fejlődés,

ökológiai lábnyom,

környezeti input-output modell, ágazati kapcsolatok modellje,

budapesti várostérség
A tanulmány a budapesti várostérség környezeti hatásait vizsgálja 2003 és 2013 között, ökológiai lábnyom segítségével. Hasonlóan a kelet-középeurópai térség más nagyvárosához a budapesti várostérség belső térszerkezete is átalakult a rendszerváltozás után, amikor megindult a fiatalabb, vagyonosabb rétegek kiköltözése a központi városból az elővárosi övezetbe. Az elővárosi övezet gyorsan növekvő és egyre magasabb szinten fogyasztó társadalma a várostérség ökológiai lábnyomában is területi átrendeződést eredményezett. A szerzők a közvetlen lakossági ökológiai lábnyom becslése mellett a közvetett, a lakossági fogyasztási javak teljes életciklusába (nyersanyag-kitermelés, -feldolgozás, szállítás, hulladékkezelés) beépülő lábnyomot is számszerűsítik a környezeti adatokkal kiegészített ágazati kapcsolatok mérlege segítségével.

Megállapítható, hogy míg 2003 és 2013 között a lakossági fogyasztásba beépülő ökológiai lábnyom országosan 11\%-kal csökkent, addig Budapesten 6 és az agglomerációjában $8 \%$-kal nőtt. Előbbi esetében a növekedés az egy főre jutó fogyasztás bővülésével, utóbbi esetében elsősorban a népességszám növekedésével magyarázható. A lakossági közvetlen ökológiai (karbon-) lábnyom az agglomerációban 2013-ban több mint 2-szerese volt a budapestinek. Ez a magasabb (a fatüzelés újbóli térnyerése miatti) fütési lábnyom következtében alakult ki, a jármüüzemanyag-felhasználás karbonlábnyoma csak kevéssel haladta meg a budapesti lábnyomot. Az összesített háztartási fogyasztási ökológiai lábnyomának értékei - egy főre 2013-ban Budapesten 2,5, az agglomerációban 2,8 globális hektár (gha) - alapján megállapítható, hogy a várostérség ökológiai lábnyoma nagyon koncentrált, Budapesten 2013-ban 32-szeresével (2003-ban 37-szeresével), az agglomerációban 2013-ban 2,4-szeresével (2003-ban 2,2-szeresével) haladta meg a rendelkezésre álló biokapacitást.

Területi Statisztika, 2019, 59(1): 97-123; DOI: 10.15196/TS590105 
Keywords:

suburbanization, sustainable development, ecological footprint, environmentally extended input-output analysis, Budapest Metropolitan Region
In this paper, the environmental impacts of the transformation of the Budapest metropolitan region are studied between 2003 and 2013, through the ecological footprint indicator. The socio-spatial structure of the Budapest metropolitan region, like that of other major urban agglomerations in East Central Europe, has gone through substantial changes since the regime change, when the young, affluent strata started to move from the core city to the suburban zone. The quickly growing population of suburbs, with higher level of consumption has resulted in a regional reshuffle of the ecological footprint of the urban region. In this paper, beyond estimating the direct household ecological footprint, the indirect household footprint is calculated, embedded in the total life-cycle of goods and services (raw material extraction, processing, transportation, waste management) consumed by households, using an environmentally extended input-output model.

Although the indirect, embedded household footprint decreased by $11 \%$ in Hungary between 2003 and 2013, it increased by $6 \%$ in Budapest and by $8 \%$ in the suburban zone. It is mainly the outcome of population growth in the suburban area and the increase in per capita consumption in Budapest. The direct household ecological (carbon) footprint of the suburban zone was double the value of $\mathrm{Bu}$ dapest in 2013. This was mainly due to the higher heating footprint (due to spreading wood combustion), whereas, there was no significant difference regarding the carbon footprint of fuels used by vehicles. Based on total household ecological footprint (that amounted to 2,5 gha/capita in Budapest and 2,8 gha/capita in the suburban zone), it seems that the ecological footprint of the metropolitan region is extremely concentrated in the metropolitan region, in 2013 it exceeded the available biocapacity by 32-fold (in 2003 by 37-fold) in Budapest and by 2.4-fold (in 2003 by 2,2-fold) in the suburban zone.

Beküldve: 2018. július 30.

Elfogadva: 2018. augusztus 30.

Területi Statisztika, 2019, 59(1): 97-123; DOI: 10.15196/TS590105 


\section{Bevezetés}

A rendszerváltozást követően gyökeres változás következett be a posztszocialista térség városfejlődésében (Enyedi 2010). 1990 előtt a szigorú területrendezésihatósági szabályozás, valamint az állam dominanciája a lakáspiacon megakadályozta a népesség erőteljesebb kiáramlását az elővárosi terekbe, a gazdaság területi dekoncentrációját pedig a technológiai színvonal tette lehetetlenné, a tömegszériában termelő, sok tekintetben a fordi gyáriparra emlékeztető szocialista nagyipar erősen rá volt utalva a városokra. Mindezek eredményeként az ipari forradalom kitermelte „kompakt” város a szocializmus évtizedeiben tartósan fennmaradt, a szuburbanizációnak csak elvétve mutatkoztak jelei, s ezek is inkább a térség nagyvárosai körül (Kovács 2017). Ebbe a térstruktúrába „robbant bele” a rendszerváltozás, s hozott igen rövid idő alatt jelentős fordulatot. Megindult a népesség és a gazdaság „kirajzása" az elővárosi terekbe, a városi szétterülés (urban sprawl) a korábbi kompakt városokat szétfeszítette, az elővárosi övezet egyre kevésbé volt ráutalva a magvárosra, s a kialakuló új térkapcsolatokra az erősödő mobilitás mellett egyre inkább a reciprocitás volt a jellemző (Stanilov-Sýkora 2014, Szabó et al. 2014, Pichler-Milanović 2014).

A posztszocialista várostérségek rendszerváltozás utáni átalakulása, a tömeges szuburbanizáció jelentôs társadalmi és környezeti hatásokkal járt. Mivel az elővárosi övezetbe döntően fiatalabb és tehetősebb népesség költözött, emelkedett az övezet társadalmi státusa, nőtt a fogyasztás és a jólét szintje. Környezeti szempontból kiemelhető a beépítés növekedése, a természetes felszínek zsugorodása, a bővülő motorizáció, ami jelentôs nyomást gyakorolt a környezetre (Schmidt et al. 2015, Václavík-Rogan 2009). A nemzetközi szakirodalom alapján megállapítható, hogy a szuburbanizáció társadalmi-gazdasági következményei viszonylag alaposan feltártak (Hirt 2007, Kovács-Tosics 2014, Leetmaa et al. 2009, Ouředníček 2007), miközben a környezeti hatásokra eddig kevés figyelem irányult. A városfejlődés környezeti hatásai túlmutatnak az adott földrajzi területen, ezért vizsgálatukhoz olyan módszertani eszközökre és indikátorokra van szükség, amelyek ezt kezelni tudják. Tanulmányunkban a budapesti várostérségre vonatkozóan erre teszünk kísérletet a nemzetközi szakirodalomban az 1990-es évek közepétől használt ökológiai lábnyom (Wackernagel-Rees 1996) elméleti és módszertani eszköztárának alkalmazásával.

Az ökológiai lábnyom, amely egy adott területen élő népesség (vagy egyéb meghatározott egység) természetierőforrás-felhasználását számszerűsíti, alkalmas a várostérség növekedése, valamint a szuburbanizáció nyomán bekövetkező változások kimutatására. A mutató segítségével számszerúsíthető az a problémakör is, hogy a városok, illetve agglomerációik természetierőforrás-felhasználása nemcsak a földrajzi határaikon belül jelentkezik, hanem azokon túl is. Ennek egyik fő oka, hogy a városi lakosság által elfogyasztott javak többségét máshol állítják elő, miközben az adott várostérség környezeti hatásaihoz köthető.

Területi Statisztika, 2019, 59(1): 97-123; DOI: 10.15196/TS590105 
A tanulmány a lakossági (termék- és szolgáltatás-) fogyasztásba beépülő, közvetett ökológiai lábnyom számítására vállalkozik, a környezetileg kiterjesztett ágazati kapcsolatok mérlege (ÁKM) alapján. Az ÁKM segítségével a fogyasztási javak teljes életciklusának (nyersanyag-kitermelés, -elóállítás, szállítás, -felhasználás) ökológiai lábnyomát számszerűsíteni tudjuk. Ezt egészíti ki az ökológiai lábnyom közvetlenül a lakosság által generált részének (a fütésből és a személygépkocsi-használatból származó szén-dioxid-kibocsátás) becslése.

A tanulmány főbb kutatási kérdései:

- Milyen hatással volt a városi szétterülés (urban sprawl) a budapesti várostérség ökológiai lábnyomára?

- Hogyan alakult Budapest és az agglomeráció fogyasztási javakba beépülő ökológiai lábnyoma a 2008-as gazdasági világválság előtt és után?

- Milyen fóbb különbségek figyelhetôk meg a budapesti és az agglomerációs ökológiai lábnyom szerkezetében?

A tanulmányban először áttekintjük a városfejlődés fôbb tendenciáit, kihívásait a vizsgált várostérségben, majd kitérünk az ökológiai lábnyom koncepciójának és a városfejlődéssel kapcsolatos felhasználhatóságának bemutatására. Ezt követi a módszertan ismertetése, egyrészt a vizsgált budapesti várostérségre, másrészt az ökológiai lábnyom tanulmányunkban történő számítási módjára vonatkozóan. Az eredmények áttekintését a városfejlődési folyamatokhoz kapcsolódó értelmezés követi. A tanulmányt összegzés és rövid kitekintés zárja.

\section{A budapesti várostérség fejlödése és kapcsolata a terület öko- lógiai lábnyomával}

A rendszerváltozás után jelentős területi átalakulás zajlott le Budapest várostérségében, amelynek elsőszámú nyertese - a meginduló szuburbanizáció révén - az elővárosi övezet volt (Dövényi-Kovács 1999, Kovács-Egedy 2016). A főváros lakónépessége 1990 és 2010 között közel 300 ezer fôvel csökkent, ami egyrészt a természetes fogyás (kétharmad részben), másrészt a népesség elővárosi övezetbe történő kiköltözésének eredménye. A főváros lakónépességének csökkenése különösen az 1990-es évek végén és a 2000-es évek elején volt gyors, a népességfogyás üteme akkoriban elérte az évi 18-20 ezer főt. Ezt követően a fóváros vándorlási vesztesége folyamatosan mérséklődött, majd 2008 után ismét nőtt. Ezzel szemben az agglomerációs övezet mérsékelt természetes fogyását a fốvárosból kiköltözők jelentős száma ellensúlyozta, a hivatalosan nyilvántartott agglomerációs övezet népessége 1990 és 2010 között 44\%-kal nőtt. Az ezredfordulót követően az elővárosi övezet népességgyarapodásában már az ország más részeirôl (fóként Kelet-Magyarországról) ide irányuló vándorlás is egyre fontosabb szerepet játszott.

A szuburbanizáció népesség szempontjából kitüntetett célterülete elsősorban az agglomeráció nyugati és észak-nyugati övezete volt, amely vonzó természeti adottságaival színvonalas lakókörnyezetet biztosított a kiköltöző, főként magasabb

Területi Statisztika, 2019, 59(1): 97-123; DOI: 10.15196/TS590105 
státusú rétegek számára (Dövényi-Kovács 1999). A népesség szuburbanizációja mellett az 1990-es évek közepétól már a gazdaság, a munkahelyek szuburbanizációja is megfigyelhető, ami elsősorban új ipari parkok, nagy kiterjedésú irodakomplexumok megjelenését és különböző nagy- és kiskereskedelmi beruházásokat jelentett, döntően a nagyvárosi periféria fő közlekedési tengelyei mentén. A várostérségen belül ezzel a munkahelyek súlypontja egyre inkább az elővárosi övezet felé tolódott, ráerősítve a korábbi migrációs irányokra. Az elővárosi övezet alárendelt szerepe, egyoldalú függése Budapesttől mindezek következtében jelentősen mérséklődött, miközben az övezet társadalmi státusa folyamatosan emelkedett. A várostérségen belüli társadalmi-gazdasági átrendeződés a fogyasztás térszerkezetére is hatással volt, hiszen az övezet gyorsan növekvő, vagyonosabb népessége abszolút és relatív értelemben egyaránt magasabb szintű fogyasztást generált.

Az ökológiai lábnyom már a megjelenése óta (Rees 1992, Wackernagel-Rees 1996) népszerú környezeti, fenntarthatósági indikátornak számít. A koncepció lényege, hogy egy adott népesség vagy gazdaság szükségleteinek a hosszú távú kielégítéséhez szükséges területet számszerúsíti. Az ökológiai lábnyom mutató 6-féle területtípust vesz figyelembe (Csutora 2011), ezek közül 5, a fizikai valóságban is megjelenő terület (szántóföld, legelő, halászati terület, erdő, beépített terület), illetve egy fiktív (karbonelnyelô terület vagy karbonlábnyom, ezt leggyakrabban a kibocsátott szén-dioxid elnyeléséhez szükséges erdőterület nagyságával közelítik) és ezt vetíti a rendelkezésre álló területre (biokapacitás).

Az ökológia lábnyom a megfogalmazott kritikai észrevételek ellenére - csak az erőforrás-használatra koncentrál, a szennyezést nem veszi figyelembe, így lehet, hogy a nagyüzemi mezőgazdaság ökológia lábnyoma alacsonyabb az ökológiai gazdálkodásénál (Csutora et al. 2011), illetve számos egyéb kisebb-nagyobb módszertani kérdés sincs tisztázva - máig az egyik legelterjedtebb fenntarthatósági mutató. Előnye egyrészt a könnyú értelmezhetőség, másrészt alkalmas a vizsgált területen kívül megjelenő, de az adott területhez köthető környezeti hatások értékelésére is. Ez fontos a várostérségek környezeti hatásainak vizsgálata szempontjából, hiszen az itt elfogyasztott javak többsége más régiókból vagy más országokból származik (import), az ok-okozati kapcsolatokat tekintve azonban az elóállításukhoz, szállításukhoz kapcsolódó környezeti hatások az adott várostérséghez tartoznak. A „lábnyom” koncepciók népszerűségét mutatja, hogy számos egyéb területen is használják (víz-, energia-, sőt, akár társadalmi lábnyom, lásd Cucek et al. 2012, Harangozó et al. 2016).

Az ökológiai lábnyom számítása kétféleképpen történhet (Csutora et al. 2011).

- top-down megközelítésben, mely az eredeti, Wackernagel és Rees (1996) által kidolgozott logikát követi, nemzeti szinten aggregált adatok alapján;

- bottom-up megközelítésben (Simmons et al. 2000), egyéni adatok (kérdőívek, vállalati adatbázisok) alapján.

Területi Statisztika, 2019, 59(1): 97-123; DOI: 10.15196/TS590105 
Az ökológiai lábnyom területi alkalmazásánál további két szemléletet különböztethetünk meg. Az egyik a termelési alapú (azaz az adott területen a megadott idószakban végzett gazdasági tevékenység összesen mekkora ökológiai lábnyommal jár). A másik a fogyasztási alapú (az adott területen és időszakban megvalósuló fogyasztáshoz szükséges javak elóállitása - az adott vagy más területen - összesen mekkora lábnyomot jelent).

Peters és Hertwich (2008), illetve Vetőné Mózner (2012) érvelése alapján a fogyasztási szemléletú megközelítés előnye, hogy jobban figyelembe veszi a környezeti hatások kapcsán a felelősségi viszonyokat. Például az importált termékek ökológiai lábnyomát a fogyasztónál számolják el (vö. Dobos-Csutora 2010), és így eredményesebb intézkedéseket tesz lehetôvé, még akkor is, ha a fogyasztási szemléletû ökológiailábnyom-számítás módszertanilag sokkal összetettebb. Tanulmányunkban a budapesti várostérség ökológiai lábnyomának elemzése során a fogyasztási alapú megközelítést követtük.

Az ökológiai lábnyomot eredetileg nemzeti szintű vizsgálatokra fejlesztették ki, de az elmúlt évtizedben megjelentek egyéni, szervezeti és regionális szintủ alkalmazásai is (GFN 2012). A fogyasztási alapú megközelítésnél lehetôvé válik a teljes végső fogyasztás ökológiai lábnyomának vagy egy-egy szegmensének (háztartási vagy kormányzati) számítása (Wiedmann et al. 2006). Collins és szerzőtársai (2006) jelentős mértékben hozzájárultak a szubnacionális (regionális vagy városi szintú) ökológiailábnyom-számítás módszertanának fejlődéséhez. Az egyik úttörő, regionális, háztartási fogyasztáson alapuló ökológiailábnyom-számítás Walesre vonatkozott (Barrett et al. 2005), ahol a kapott eredmények (Cardiff város: 5,59 gha/fó, Wales: $5,25 \mathrm{gha} / \mathrm{fö)}$ közvetlenül összevethetők Nagy-Britannia országos értékével (5,31 gha/fö).

A városok növekedése és szétterülése, a szuburbanizáció világszerte gyorsan alakítja a várostérségek belső szerkezetét, és az ökológiai lábnyom várostérségen belüli területi egyenlőtlenségeinek, illetve a területi és társadalmi átalakulás ökológiai lábnyomra kifejtett hatásának feltárása (kellő óvatossággal), de szintén megkezdődött. Amellett, hogy a szuburbanizáció közvetlen módon számos kedvezőtlen ökológiai következménnyel jár (felszíni fragmentáció, növekvő zsúfoltság, ökológiai funkciók csökkenése, károsodása vö. Bohnet-Pert 2010, Piña-Martinez 2014, Gu et al. 2015), általában növeli a fajlagos ökológiai lábnyomot is (Fang et al. 2018). Egy adott várostérségen belüli, a területi különbségekre fókuszáló elemzések elsősorban azt a dilemmát helyezik a középpontba, hogy a kompakt város vagy a szétterülő és alacsonyabb beépítettséggel rendelkező nagyváros tekinthető-e kedvezőbb településformának az ökológiai lábnyom szempontjából. A kérdés megválaszolása összetett feladat, a tudományos kutatás ezért elsősorban egyes tevékenységek (ingázás, energiafelhasználás, háztartási fogyasztás stb.) ökológiai lábnyomainak összehasonlítására vállalkozik. A várostérségek formai jegyeire koncentráló elemzések általában egyetértenek abban, hogy az ingázás jelentősen megnöveli a háztartási karbonlábnyomot,

Területi Statisztika, 2019, 59(1): 97-123; DOI: 10.15196/TS590105 
így a kompakt város ökológiai szempontból kedvezőbbnek tekinthető (MuñizSánchez 2018). Egy, az egyesült államokbeli metropoliszrégiókat vizsgáló kutatás bizonyította azt is, hogy minél nagyobb a központi városmag, annál gyorsabban növekszik a várostérség háztartási karbonlábnyoma, mert óriásira nő az ingázási övezete (Jones-Kammen 2014). A szétterülő várostérségeknél a belső szerkezet esetenként nagy hangsúlyt kap: egy monocenrikus régióban az ingázásból eredő kedvezőtlen hatások nagyobbak, mint egy policentrikusban, ahol az ingázási útvonalak átrendeződésével a karbonlábnyom változása ellentmondásos, és több más tényezôtól (elsősorban jövedelemtôl) is függ (Muñiz-Galindo 2005, BurgalassiLuzzati 2015).

Amennyiben nemcsak az ingázást, hanem más tényezőket is figyelembe veszünk (a jövedelemtől függő háztartási fogyasztást), akkor egy várostérségen belül, a város növekedésével párhuzamosan nagyobb mértékben emelkedhet a központi mag egy főre jutó ökológiai lábnyoma. A nagy népsűrűségű központi város ugyanis sokrétű gazdaságot és magasabb jövedelmú népességet integrál, ez pedig oda vezet, hogy az ingázás hiányából eredő kedvező hatásokat a megugró fogyasztás lerontja. Ezt a jelenséget Heinonen és szerzőtársai (2011) és Heinonen-Junilla (2011) Helsinki példáján írták le. Ha az egy háztartásra jutó lábnyommal számolunk, a városközpont még kedvezőtlenebb helyzetbe kerül, mivel a szuburbán térségben általában nagyobb a háztartásméret (Ala-Mantila et al. 2013). A magasan képzett népességgel rendelkező, gazdag, zárt szuburbán lakóparkokban az ingázás és a magas fogyasztás jelentősen növeli az ökológiai lábnyomot (Rashid et al. 2018), de a külvárosi zóna összességében mégis alacsonyabb jövedelmű térségnek számít. Mindez arra hívja fel a figyelmet, hogy az ökológiai lábnyom várostérségen belüli értelmezésekor nagy figyelmet kell fordítani a jövedelmi és demográfiai viszonyokra. A nemzetközi elemzéseknél számításba kell vennünk az eltérő közigazgatási beosztást és a települési fogalmakat, mivel az egyes országok között nagy különbségek vannak a „kö̈ponti város" és a „szuburbia” lehatárolása terén (Kondor 2016).

A területi elemzésekkel szemben, az ökológiai lábnyom különböző városrészek közötti időbeli alakulásáról kevés elemzés született. Az egyes tanulmányok az időbeliséget általában modellszerúen érintik (Lu-Chen 2017), a várostérségek növekedését vagy a szuburbanizációt időben azonos intenzitású folyamatként, adottságként jelenítik meg. Az eddigi kutatások általában egy adott időpontban lezajlott adatfelvételre (népszámlálás, kérdőíves adatgyűjtés) koncentráltak, a tér és az idő együttes vizsgálata a szuburbanizáció, valamint a nyomában járó urban sprawl viszonylatában még nem terjedt el. Ez pedig szükséges ahhoz, hogy pontosan meghatározzuk az ökológiai lábnyom egy-egy várostérség központi és külvárosi területei közötti eltéréseinek hátterét, folyamatait.

Magyarországon eddig kevés, városra vonatkozó ökológiailábnyom-számítás készült. Elsőnek Kiss és Girán (2004) vetették fel az ökológiai lábnyom mint indikátor alkalmazhatóságát a Pécs Ökováros - Mecsek-Dráva Ökorégió program elemzése

Területi Statisztika, 2019, 59(1): 97-123; DOI: 10.15196/TS590105 
kapcsán, de részletes számításokat nem végeztek. Szigeti (2010) Győrre készített számításokat, részben a KSH fogyasztási adataira, részben saját adatgyújtésre alapozva. Ennek eredményei kimutatták, hogy egyrészt egy győri lakos átlagos ökológiai lábnyoma (4,33 gha/fó) meghaladta az átlagos magyarországi értéket (3,5 gha/fó), másrészt Győr teljes lábnyoma 17-szerese a rendelkezésre álló területének. Ez utóbbi alapján jól látható, hogy az ökológiai lábnyom térben főként a várostérségekre koncentrálódik, ez azért jelentős, mert a tanulmányban felmerülő adathiány miatt ezek a számítási értékek a valós ökológiai lábnyom alsó becslésének tekinthetők.

Kovács és szerzôtársai (2017) a budapesti várostérségre vizsgálták a közlekedés, illetve ezen belül az ingázás ökológiai lábnyomát (különféle közlekedési módokkal megtett távolságok alapján, azaz bottom-up jellegú módszertannal). Vizsgálatukban az ökológiai lábnyom karbon összetevőjére fókuszálva megállapították, hogy az ingázás által generált ökológiai lábnyom jelentôsen nőtt a rendszerváltozás óta és az ökológiai lábnyom egyik meghatározó részét képezi.

A tanulmányban a budapesti várostérség ökológiai lábnyomát számítjuk ki a háztartási fogyasztás alakulása alapján, beleértve a közvetlen, a közvetett (az elfogyasztott javak ellátási lánca során, akár máshol jelentkezô) ökológiai lábnyomot is.

\section{Módszertan}

\section{A mintaterület lehatárolása}

Vizsgálatainkhoz egy korábbi tanulmányunkban lehatárolt funkcionális várostérséget vettük alapul (Kovács et al. 2017), mivel az érvényben levő 1997-es kormányrendeletben (89/1997. V.28. kormányrendelet) lehatárolt budapesti agglomerációt az időközben bekövetkezett népességmozgás és területi fejlődés következtében nem tekinthettük megfelelő földrajzi keretnek. A lehatároláshoz a 2001. évi népszámlálás adatait vettük figyelembe, és a budapesti várostérséghez soroltunk minden olyan települést, ahol a népszámlálás időpontjában a foglalkoztatottak legalább 15\%-a Budapestre járt dolgozni. Lehatárolásunk ezzel igazodott az Európai Unió és a Gazdasági Együttmúködési és Fejlesztési Szervezet (Organisation for Economic Co-operation and Development - OECD) által a funkcionális várostérségek (Functional Urban Area - FUA) kijelölésénél használt küszöbértékhez. A vizsgált terület határainak pontos kijelölésénél területi harmonizációt hajtottunk végre, ahol figyelmen kívül hagytunk minden leszakadó, a kompakt tömbbel nem érintkező, úgynevezett exklávé települést, illetve beemeltünk minden küszöbérték alatti ingázással rendelkezô, de a kompakt várostérségen belül szigetet képezô, úgynevezett enklávé települést. Ennek eredményeként a budapesti várostérséget a fôvárossal és az azt körülvevő, 185 települést magában foglaló tágabb elôvárosi övvel azonosítottuk (1. ábra). Az általunk lehatárolt budapesti várostérség hazánk meghatározó téregysége, ahol a hazai népesség 29 és a munkahelyek 56\%-a koncentrálódott. A vá-

Területi Statisztika, 2019, 59(1): 97-123; DOI: 10.15196/TS590105 
rostérség országon belüli részesedését népesedési és gazdasági szempontból is növelni tudta 1990 óta.

\section{A Budapesti várostérség vizsgált települései népességnagyság-kategóriák szerint, 2001*}

1. ábra

Settlements of the Budapest metropolitan region

by population size category

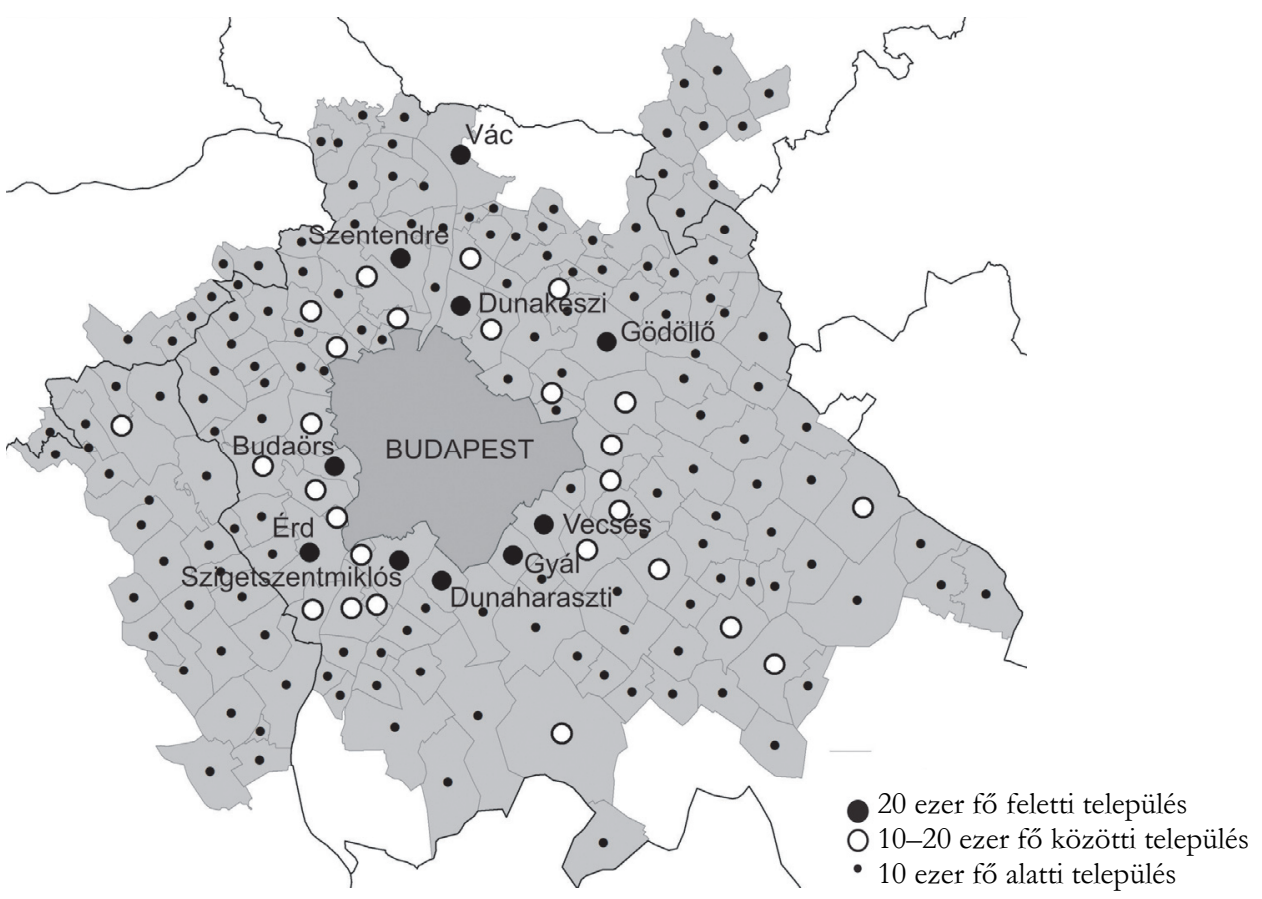

* Ingázók aránya meghaladja a 15\%-ot.

Forrás: KSH Népszámlálási adatai alapján saját szerkesztés.

\section{Az ökológiai lábnyom számítása}

A háztartási fogyasztás ökológiai lábnyomának kiszámítása a tanulmányban két részből áll. Először kiszámítottuk a háztartások által fogyasztott javak közvetett (az ellátási láncba beépülő) ökológiai lábnyomát, majd ezt követően a háztartási fogyasztás során generált közvetlen (fütés, üzemanyag-felhasználás során kibocsátott szén-dioxidhoz kapcsolódó) lábnyomot.

A lakossági (termék- és szolgáltatás-) fogyasztásba beépülő ökológiai lábnyom számítása a környezeti információkkal kiegészített ÁKM alapján történt, felhasználva a KSH lakossági fogyasztási adatait (Budapestre és az agglomerációra 2003-ra, illetve 2013-ra). Az ÁKM vagy más néven input-output modell (Leontief 1936-os munkájára

Területi Statisztika, 2019, 59(1): 97-123; DOI: 10.15196/TS590105 
épül) lényege, hogy egy gazdaságban nyomon kövesse az egyes ágazatok egymásra épülését, megmutatva azt, hogy egy egységnyi termelés az egyik ágazatban mennyi erőforrást igényel a többi ágazatból. Például egy futball-labda elóállítása mekkora hozzájárulást igényel a bőripartól, az energiaszektortól és a szállitási ágazattól stb. A környezeti adatokkal kiegészített input-output elemzés (environmentally extended inputoutput analysis - EEIO) alkalmas a háztartási fogyasztás ökológiai lábnyomának meghatározására (a korábbi csoportosítás alapján, top-down megközelítésben).

Az input-output modellt ökológiai lábnyom számítására először Bicknell és szerzőtársai (1998), illetve Ferng (2001) használták. Az első magyarországi alkalmazás Csutora és szerzőtársai (2011) nevéhez fűződik, akik a háztartási fogyasztás ökológiai lábnyomát határozták meg így.

A tanulmányban a módszer regionális szintú alkalmazását végeztük el Wiedmann és szerzőtársai (2006) módszertani útmutatása alapján.

A lakossági fogyasztás beépülő ökológiai lábnyomát az

$\mathrm{EF}=\mathrm{EF}_{\text {dir }} *(\mathrm{I}-\mathrm{A})^{-1} * \mathrm{FD}$

összefüggés alapján számítottuk ki, ahol $\mathrm{EF}$ jelenti az ökológiai lábnyomot, $\mathrm{EF}_{\text {dir }}$ az egyes szektorok közvetlen fajlagos ökológiai lábnyomát (például egy millió forint építóipari termelés mekkora ökológiai lábnyomot indukál Magyarországon). Az (I-A)-1 összetevő az ÁKM-ből származtatott Leontief-inverz mátrix, míg FD az adott területre, illetve időszakra vonatkozó lakossági fogyasztás vektora (mekkora értékú volt a lakossági fogyasztás a különböző szektorokban, a vizsgált időszakban). Míg az $\mathrm{EF}_{\text {dir }}$ vektort a Global Footprint Network (GFN 2011) magyarországi adatbázisa alapján határoztuk meg, addig a mintaterületekre vonatkozó FD fogyasztási vektorok a KSHadatgyújtéséből származó vásárolt adatok. (A módszertant itt nem részletezzük, a főbb elemek megtalálhatók Wiedmann és szerzőtársai [2006] munkájában.)

A fogyasztási javakba beépülő, közvetett lábnyomon kívül a lakossági fogyasztáshoz kapcsolódó ökológiai lábnyomnak közvetlen összetevői is vannak (amelyek közvetlenül a háztartásoknál keletkeznek). Ezeket a KSH fogyasztási adatai alapján számszerűsítettük. A közvetlen ökológiai lábnyom összetevői az ökológiai lábnyom két területén jelennek meg:

- Karbonlábnyom, amely a lakossági fútés és járműüzemanyag-felhasználás által generált szén-dioxid-kibocsátás következménye. Ide tartozik például a fatüzelés, illetve a személygépkocsi által generált szén-dioxid-kibocsátás. Nem tartozik ide a villanyfútés (az elektromos áram felhasználása nem jár közvetlenül szén-dioxid-kibocsátással, az elóállítás, szállítás, kazángyártás stb. során jelentkező kibocsátás már benne van a beépülő lábnyomban) vagy a távolságiautóbusz-közlekedés (már beszámítottuk a közlekedési szolgáltatás vásárlása során).

- Beépített területlábnyom, amely a lakóingatlanokhoz, illetve - a háztartási használat arányában - az utakhoz kapcsolódik.

Területi Statisztika, 2019, 59(1): 97-123; DOI: 10.15196/TS590105 
A háztartási közvetlen karbonlábnyom számítása a következő lépések alapján történt:

- A KSH fogyasztási felmérésben szereplő tüzelőanyagokra (vezetékes gáz, palackos gáz, folyékony tüzelőanyagok, szén, brikett, koksz, túzifa), illetve jármúüzemanyagokra (benzin, gázolaj) fordított összegek meghatározása háztartási, egyéni szinten, a KSH-adatok alapján a vizsgált mintaterületekre és évekre vonatkozóan.

- Átlagárak (KSH) alapján a felhasznált mennyiségek meghatározása.

- A fütőértékek (GJ/mennyiségi egység), illetve a fajlagos szén-dioxidkibocsátási értékek ( $\left.\mathrm{CO}_{2} / \mathrm{GJ}\right)$ alapján az éves egy főre jutó szén-dioxidkibocsátás meghatározása (t $\mathrm{CO}_{2} /$ fô) .

- A szén-dioxid területkoefficiense alapján (Global Footprint Network GFN-adatbázis) az egy főre jutó karbonlábnyom (gha/fő) számítása.

A közvetlen beépített területlábnyom - azaz a háztartások által birtokolt ingatlanok összterületének, illetve a közutak területének háztartási használatú részének beszámítására a tanulmányban nem volt lehetôség, így a kapott eredmény a valós ökológiai lábnyom alsó becslésének tekinthetô. (Az említett lábnyomrészt a fogyasztási javakba beépülő ökológiai lábnyom tartalmazza.)

\section{Eredmények}

\section{A fogyaszłásba beépülő közvetett háztartási ökológiai lábnyom}

Az adatok alapján többféle tendencia rajzolódott ki, aszerint, hogy az abszolút vagy az egy főre jutó ökológiai lábnyom értékeket vizsgáltuk.

Az abszolút közvetett ökológiai lábnyom értékeit elemezve megállapítható, hogy a lakossági fogyasztásba beépülő lábnyomon belül a három legjelentősebb a szántóföld, a karbonelnyelő és az erdőterület (ebben a sorrendben, mind országosan, Budapestre és az agglomerációra vonatkozóan, illetve a 2003-as és 2013-as évben). A legfontosabb három összetevő az abszolút beépülő lábnyom 95\%-áért felelős, a másik három összetevő (legelő, beépített és halászati terület) együttes részesedése $5 \%$ alatti minden vizsgálati szempont esetén. Az 1. táblázatban szereplő eredményeket az országos adatokkal összehasonlítva (GFN-adatbázis) látható, hogy országosan a három kisebb összetevő együttes hozzájárulása 7-8\% közötti.

A lakossági fogyasztásba beépülő ökológiai lábnyom eltérő irányú változást mutatott a különböző területi egységeknél 2003 és 2013 között. Míg országosan 11\%-kal csökkent, addig Budapesten 6, az agglomerációban 8\%-kal emelkedett.

Területi Statisztika, 2019, 59(1): 97-123; DOI: 10.15196/TS590105 


\section{A lakossági fogyasztás abszolút közvetett ökológiai lábnyoma} területhasználat szerint

Absolute indirect ecological footprint of household consumption

by land use in 2003 and 2013

\begin{tabular}{|c|c|c|c|}
\hline Területhasználat & 2003 & 2013 & Változás, \% \\
\hline & \multicolumn{3}{|c|}{ Magyarország } \\
\hline Szántóföld & 8547170 & 6977139 & $-18,4$ \\
\hline Legelő terület & 568562 & 464123 & $-18,4$ \\
\hline Erdőterület & 2265422 & 3100958 & 36,9 \\
\hline Halászati terület & 139318 & 141095 & 1,3 \\
\hline Beépített terület & 326721 & 304497 & $-6,8$ \\
\hline Karbonelnyelő terület & 7856637 & 6615007 & $-15,8$ \\
\hline \multirow[t]{2}{*}{ Összesen } & 19703829 & 17602820 & $-10,7$ \\
\hline & \multicolumn{3}{|c|}{ Budapest } \\
\hline Szántóföld & 1524947 & 1622189 & 6,4 \\
\hline Legelő terület & 101440 & 107909 & 6,4 \\
\hline Erdőterület & 410241 & 616096 & 50,2 \\
\hline Halászati terület & 29889 & 36085 & 20,7 \\
\hline Beépített terület & 65461 & 68285 & 4,3 \\
\hline Karbonelnyelő terület & 1496010 & 1403731 & $-6,2$ \\
\hline \multirow[t]{2}{*}{ Összesen } & 3627988 & 3854294 & 6,2 \\
\hline & \multicolumn{3}{|c|}{ Agglomeráció } \\
\hline Szántóföld & 1001000 & 1041426 & 4,0 \\
\hline Legelő terület & 66587 & 69276 & 4,0 \\
\hline Erdőterület & 270321 & 420891 & 55,7 \\
\hline Halászati terület & 18005 & 16562 & $-8,0$ \\
\hline Beépített terület & 38214 & 39040 & 2,2 \\
\hline Karbonelnyelő terület & 908224 & 894716 & $-1,5$ \\
\hline Összesen & 2302352 & 2481911 & 7,8 \\
\hline
\end{tabular}

A változást egyrészt a népességszám, másrészt az egy főre jutó fogyasztás nagyságának és szerkezetének alakulása magyarázza. Budapest és az agglomeráció népességszámának alakulása 2003 és 2013 között eltért egymástól, illetve az országos ten-

Területi Statisztika, 2019, 59(1): 97-123; DOI: 10.15196/TS590105 
denciától is. Míg országosan a népesség száma 2\%-kal csökkent (10 142362 főről 9987908 fóre), addig Budapesten 2\%-kal (1 705309 főről 1744665 főre), az agglomerációban pedig 10\%-kal emelkedett (1 053448 főről 1155338 főre). Mindez azonos életvitelt - ceteris paribus - feltételezve is hozzájárul az időbeli eltérésekhez. Budapesten 2004 körül lassult, majd megállt a vándorlási veszteségből (szuburbanizáció) adódó gyors népességfogyás. A népességszám a 2008-as gazdasági világválságot követő években nőtt, amelynek több forrása volt (az agglomerációból és vidékről vissza-, illetve beköltözők, valamint a külföldiek). Bár az agglomerációs zóna népességnövekedését visszafogta a válság, a Budapesthez közeli települések többségének lakosságszáma így is évrôl évre folyamatosan emelkedett. Egyrészt folyamatos volt a vidéki térségekről a bevándorlás, másrészt a fiatalos korösszetétele okán a természetes fogyás is kisebb volt az országos átlagnál, sőt, nem egy települést természetes szaporodás jellemzett (Dövényi 2007, 2009, KSH 2012a, 2012b).

Az ökológiailábnyom-értékek változásának másik meghatározója a fogyasztási szerkezet, azaz az egy főre jutó ökológiai lábnyom.

2. táblázat

\section{A lakossági fogyasztás egy főre jutó közvetett ökológiai lábnyoma területhasználat szerint}

Indirect per capita ecological footprint of household consumption by land use in 2003 and 2013

\begin{tabular}{l|r|r|r|r|r|r|r|r|r}
\hline \multirow{2}{*}{ Területhasználat } & \multicolumn{3}{|c|}{ Magyarország } & \multicolumn{3}{c|}{ Budapest } & \multicolumn{3}{c}{ Agglomeráció } \\
\cline { 2 - 10 } & 2003 & 2013 & $\begin{array}{c}\text { változás, } \\
\%\end{array}$ & 2003 & 2013 & $\begin{array}{c}\text { változás, } \\
\%\end{array}$ & 2003 & 2013 & $\begin{array}{c}\text { változás, } \\
\%\end{array}$ \\
\hline Szántóföld & 0,84 & 0,70 & $-16,7$ & 0,89 & 0,93 & 4,5 & 0,95 & 0,90 & $-5,3$ \\
Legelő terület & 0,06 & 0,05 & $-16,7$ & 0,06 & 0,06 & 0,0 & 0,06 & 0,06 & 0,0 \\
Erdőterület & 0,22 & 0,31 & 40,9 & 0,24 & 0,35 & 45,8 & 0,26 & 0,36 & 38,5 \\
Halászati terület & 0,01 & 0,01 & 0,0 & 0,02 & 0,02 & 0,0 & 0,02 & 0,01 & $-50,0$ \\
Beépített terület & 0,03 & 0,03 & 0,0 & 0,04 & 0,04 & 0,0 & 0,04 & 0,03 & $-25,0$ \\
Karbonelnyelő & & & & & & & & & \\
terület & 0,77 & 0,66 & $-14,3$ & 0,88 & 0,80 & $-9,1$ & 0,86 & 0,77 & $-10,5$ \\
Összesen & $\mathbf{1 , 9 4}$ & $\mathbf{1 , 7 6}$ & $\mathbf{- 9 , 3}$ & $\mathbf{2 , 1 3}$ & $\mathbf{2 , 2 1}$ & $\mathbf{3 , 8}$ & $\mathbf{2 , 1 9}$ & $\mathbf{2 , 1 5}$ & $\mathbf{- 1 , 8}$ \\
\hline
\end{tabular}

Az egy főre jutó - lakossági fogyasztásba beépülő - ökológiai lábnyomot vizsgálva megállapítható, hogy az eltérő jövedelmi szinthez kapcsolódó különböző bázishoz képest (országos, Budapest és agglomeráció) is tovább nyílt az olló. A lakossági jövedelem és a fogyasztás értékének a 2008-as gazdasági világválság előtti szintre, illetve a fölé kapaszkodó értéke, valamint a hazai és az import termelési szerkezet

Területi Statisztika, 2019, 59(1): 97-123; DOI: 10.15196/TS590105 
átalakulásának, valamint az ökohatékonyság lassú javulásának eredőjeként míg Budapesten 4\%-os emelkedés, addig az agglomerációban 2, országosan 9\%-os csökkenés volt. A teljes ökológiai lábnyom vizsgálata azt mutatja, hogy országosan csökkent az abszolút és az egy főre jutó fogyasztási ökológiai lábnyom, Budapesten mindkét mutató értéke nőtt, az agglomerációban pedig az abszolút lábnyom méretének növekedése mellett az egy fő̉re jutó ökológiai lábnyom - bár az országos szintnél kisebb ütemben - csökkent (2. táblázat) (Kondor-Kovács 2017).

Budapesten a növekedés fő oka a jövedelem és a lakossági fogyasztás országos átlagot meghaladó mértékủ emelkedése. Az agglomerációban a népesség számának bővülése magyarázza a lábnyom méretének abszolút növekedését, ugyanakkor az agglomeráció népességének jövedelmi és fogyasztási színvonala - a fogyasztási adatok alapján - kissé elmarad a budapestitől. Ennek több oka is lehet, egyrészt az eltartott népesség aránya (a kisgyermekes családokkal összefüggésben) magasabb, másrészt a Budapest környéki települések népességét nemcsak a Budapestről kiköltöző magas státusú, hanem a fôvárosból, illetve vidékről beköltöző alacsonyabb jövedelmú népesség is gyarapítja.

Ha a lakossági fogyasztásba beépülő ökológiai lábnyomot a COICOP-besorolás (Classification of Individual Consumption by Purpose, magyarul Nemzetközi Fogyasztási Osztályozási Rendszer - az ENSZ háztartási fogyasztási kiadások fogyasztási szemléletű besorolása, ENSZ 2011, KSH é.n.) szerinti 12 fő fogyasztási kategória alapján vizsgáljuk (Fábián-Kolosi-Róbert 2008), akkor megállapítható, hogy az élelmiszerek részaránya a legjelentősebb a teljes lábnyomon belül, ezt követi a közlekedés, illetve a lakásfenntartás és háztartási energia. Ezeken kívül jelentős még a szeszes ital/dohányáru és a vendéglátás/szálláshely-szolgáltatás beépülő ökológiai lábnyoma. Az oktatás és az egészségügy alacsony ökológiai lábnyománál fontos megemlíteni, hogy tanulmányunkban csak a lakossági fogyasztás ökológiai lábnyomát vizsgáltuk, tehát itt nem jelenik meg az állami, illetve a civil szektor szerepvállalása (3. táblázat).

Budapest fogyasztási alapú beépülő ökológiai lábnyoma több mint 50\%-kal nagyobb, mint az agglomerációé. Ezt a korábban már említett népességszámból adódó különbség magyarázza. Az egy fő́re jutó lábnyom szinte ugyanakkora a két területen, de a szerkezete jelentősen eltér egymástól. 2013-ban az agglomerációban nagyobb volt az élelmiszer-fogyasztás, az energiafogyasztás és a közlekedés egy főre jutó beépülő ökológiai lábnyoma, mint Budapesten. Az agglomerációban a nagyobb átlagos ingatlanméret, illetve a fajlagosan magasabb energiaigényú családi házak magasabb aránya magyarázhatja az ingatlanfenntartáshoz kapcsolódó nagyobb lábnyomot, míg a jelentősebb közlekedési igény (ingázás) magasabb ökológiai lábnyoma is kimutatható. Ez utóbbi esetben azonban külön hangsúlyozni kell, hogy itt nem az ökológiai lábnyom közvetlen összetevőiről (az épületek, illetve az utak területe, mint beépített területlábnyom vagy a fütés, illetve közlekedés szén-dioxidkibocsátása mint karbonlábnyom) van szó, hanem továbbra is a közvetetten, 
az ellátási láncba beépülő lábnyomösszetevőkrőll (például egy személygépkocsi gyártásához, fenntartásához kapcsolódóan).

\section{A lakossági fogyasztás abszolút (gha) és egy före jutó (gha/fö) közvetett ökológiai lábnyoma fogyasztási kategóriánként}

Absolute (gha) and per capita (gha/capita) indirect ecological footprint of household consumption by categories in 2013 and their change between 2003 and 2013

\begin{tabular}{|c|c|c|c|c|}
\hline \multirow{2}{*}{ Fogyasztási kategória } & 2013 & $2013 / 2003$ & 2013 & $2013 / 2003$ \\
\hline & \multicolumn{2}{|c|}{ gha } & \multicolumn{2}{|c|}{ gha/fö } \\
\hline & \multicolumn{4}{|c|}{ Budapest } \\
\hline Élelmiszer & 1606815 & 1,05 & 0,92 & 1,02 \\
\hline Szeszes ital, dohányáru & 385590 & 1,23 & 0,22 & 1,20 \\
\hline Ruházat és lábbeli & 59550 & 0,67 & 0,03 & 0,65 \\
\hline Lakásfenntartás és háztartási energia & 456092 & 1,12 & 0,26 & 1,10 \\
\hline Lakberendezés, háztartásvitel & 115962 & 0,69 & 0,07 & 0,67 \\
\hline Egészségügy & 77726 & 1,19 & 0,04 & 1,17 \\
\hline Közlekedés & 491083 & 1,53 & 0,28 & 1,50 \\
\hline Hírközlés & 34597 & 0,79 & 0,02 & 0,77 \\
\hline Kultúra, szórakozás & 187703 & 0,62 & 0,11 & 0,60 \\
\hline Oktatás & 8894 & 0,66 & 0,01 & 0,64 \\
\hline Vendéglátás & 336786 & 1,27 & 0,19 & 1,24 \\
\hline Egyéb & 93497 & 0,94 & 0,05 & 0,92 \\
\hline \multirow[t]{2}{*}{ Összesen } & 3854294 & 1,06 & 2,21 & 1,04 \\
\hline & \multicolumn{4}{|c|}{ Agglomeráció } \\
\hline Élelmiszer & 1125568 & 1,01 & 0,97 & 0,92 \\
\hline Szeszes ital, dohányáru & 267438 & 1,45 & 0,23 & 1,32 \\
\hline Ruházat és lábbeli & 28851 & 0,57 & 0,02 & 0,52 \\
\hline Lakásfenntartás és háztartási energia & 323513 & 1,26 & 0,28 & 1,15 \\
\hline Lakberendezés, háztartásvitel & 57703 & 0,55 & 0,05 & 0,51 \\
\hline Egészségügy & 39417 & 1,30 & 0,03 & 1,19 \\
\hline Közlekedés & 363970 & 1,59 & 0,32 & 1,45 \\
\hline Hírközlés & 17502 & 0,72 & 0,02 & 0,66 \\
\hline Kultúra, szórakozás & 97420 & 0,66 & 0,08 & 0,60 \\
\hline Oktatás & 5008 & 0,77 & 0,00 & 0,70 \\
\hline Vendéglátás & 110927 & 1,05 & 0,10 & 0,96 \\
\hline Egyéb & 44594 & 0,86 & 0,04 & 0,78 \\
\hline Összesen & 2481911 & 1,08 & 2,15 & 0,98 \\
\hline
\end{tabular}

Területi Statisztika, 2019, 59(1): 97-123; DOI: 10.15196/TS590105 
Ezzel szemben Budapesten 2013-ban magasabb volt az egészségügyhöz, az oktatáshoz, a ruházkodáshoz és a szolgáltatásokhoz (telekommunikáció, szórakozás és kultúra, vendéglátás és szálláshely-szolgáltatások) kapcsolódó lábnyom értéke. Ezek inkább a nagyobb egy főre jutó jövedelemből adódó magasabb fogyasztással magyarázhatók (különösen úgy, hogy egy átlagos budapesti lakos esetében a magasabb összjövedelmen túl a fentiekkel összhangban figyelembe vesszük azt is, hogy a közlekedési és a háztartási energiával kapcsolatos kiadások alacsonyabbak, mint egy átlagos agglomerációban élő lakos esetében).

Ha a 2003-2013 közötti változásokat elemezzük, látható, hogy az agglomerációban az energiafogyasztás beépülő ökológiai lábnyoma - az egyre nagyobb energiafogyasztás miatt - lényegesen gyorsabban nőtt a budapestinél, ugyanakkor az élelmiszerekhez kapcsolódó közvetett ökológiai lábnyomnál míg a fővárosban növekedés volt mind az abszolút, mind a fajlagos lábnyomban, addig az agglomerációban csökkent az egy főre jutó érték, ezzel szúkült az agglomeráció előnye a fajlagos mutatónál. Azonban az alkoholra és a dohányárura jutó lábnyomrész nagyobb mértékben nőtt az agglomerációban. A közlekedésre fordított, egy főre jutó fogyasztás is jelentősebb mértékben emelkedett a fővárosban, mint a városkörnyéken, azzal együtt is, hogy a közlekedés abszolút közvetett beépülő lábnyoma nagyobb mértékben emelkedett az agglomerációban. A szabadidős, turisztikai (étterem, szálláshelyek igénybevétele stb.) tevékenységek lábnyoma esetében erősödött Budapest „előnye”, hiszen a magasabb jövedelem és a relatíve kisebb közlekedési és energiakiadások következtében a budapestiek többet tudtak fordítani éttermi és szállodai szolgáltatásokra.

\section{A lakossági közvetlen ökológiai lábnyom}

A lakossági fogyasztás termékekbe és szolgáltatásokba épülő ökológiai lábnyomán túl kiszámoltuk a lakossági fogyasztás által közvetlenül generált ökológiai (ezen belül karbon-) lábnyomot is.

A 4. táblázat azt mutatja, hogy az agglomerációban az egy főre jutó közvetlen karbonlábnyom sokkal nagyobb (2013-ban több mint kétszerese), mint Budapesten. A fütés és a közlekedés közvetlen lábnyoma közül az előbbi a jelentősebb ${ }^{1}$, és az agglomerációban a nagyobb érték a nagyobb közvetlen fútési lábnyommal magyarázható. 2003 és 2013 között míg az amúgy is magasabb egy főre jutó agglomerációs fütési lábnyom 22\%-kal nőtt, addig Budapesten 12\%-kal csökkent. A vezetékes gáz használata mindkét mintában visszaesett, viszont az agglomerációban a tűzifahasználat lábnyoma közel 4-szeresére nőtt. Megjegyezzük, hogy az adatok a rezsicsökkentés előtti állapotot tükrözik, és a válságból való kilábalás csak az általunk vizsgált idôszak vége után gyorsult fel. Mindemellett ez az adat is arra utal, hogy a gazdagabb

\footnotetext{
${ }^{1}$ Ismételten hangsúlyoznunk kell, hogy ez az összehasonlítás csak a közvetlen, lakossági fogyasztóknál történő széndioxid-kibocsátást tartalmazza. Nem tartozik bele például a villanyfütés, járműgyártás, karbantartás, de még a tömegközlekedés során kibocsátott emisszió sem (hiszen ezeket már a fogyasztási javakba beépülve korábban figyelembe vettük).
}

Területi Statisztika, 2019, 59(1): 97-123; DOI: 10.15196/TS590105 
kiköltözők mellett a szegényebb rétegek is nagy számban vannak jelen az agglomerációban, mert elsősorban rájuk jellemző a tűzifa használata (Fábián et al. 2008).

\section{A lakossági fogyasztás egy före jutó közvetlen karbonlábnyoma Budapesten és az agglomerációban}

Per capita direct carbon footprint of household consumption in Budapest and its agglomeration, in 2003 and 2013

4. táblázat

\begin{tabular}{|c|c|c|c|c|c|c|}
\hline \multicolumn{7}{|c|}{$\begin{array}{l}\text { Per capita direct carbon footprint of household consumption } \\
\text { in Budapest and its agglomeration, in } 2003 \text { and } 2013\end{array}$} \\
\hline & & & & & & (gha/fö) \\
\hline \multirow[b]{2}{*}{ Összetevő } & \multicolumn{3}{|c|}{ Budapest } & \multicolumn{3}{|c|}{ Agglomeráció } \\
\hline & 2003 & 2013 & $\begin{array}{l}\text { változás, } \\
\%\end{array}$ & 2003 & 2013 & $\begin{array}{l}\text { változás, } \\
\%\end{array}$ \\
\hline Gáz (vezetékes) & 0,25 & 0,22 & $-11,3$ & 0,37 & 0,31 & $-18,2$ \\
\hline Gáz (palackos) & 0,00 & 0,00 & 0,0 & 0,01 & 0,01 & 17,7 \\
\hline Folyékony tüzelőanyagok & - & - & - & - & - & - \\
\hline Szén & - & - & - & 0,01 & 0,01 & 0,0 \\
\hline Brikett, koksz & - & - & - & 0,00 & 0,00 & 0,0 \\
\hline Tűzifa & 0,01 & 0,01 & $-20,5$ & 0,06 & 0,23 & 273,0 \\
\hline Fűtés összesen & 0,26 & 0,23 & $-11,5$ & 0,45 & 0,55 & 22,2 \\
\hline Benzin & 0,06 & 0,06 & 0,0 & 0,07 & 0,07 & 7,6 \\
\hline Gázolaj & 0,02 & 0,02 & $-18,9$ & 0,03 & 0,02 & $-25,2$ \\
\hline Járműüzemanyag összesen & 0,08 & 0,08 & $-5,5$ & 0,09 & 0,09 & $-1,9$ \\
\hline Közvetlen karbonlábnyom & 0,34 & 0,31 & $-10,0$ & 0,54 & 0,64 & 18,1 \\
\hline
\end{tabular}

A jármúüzemanyag közvetlen karbonlábnyománál nincs jelentős eltérés Budapest és az agglomeráció között (körülbelül 10\%-kal magasabb az egy főre jutó agglomerációs lábnyom). Ennek értelmezése azonban összetett. Valószínúsíthető, hogy az agglomerációban lakók többet használják a személygépkocsijukat munkába járásra, míg a budapestiek a magasabb átlagos jövedelmük révén többet utaznak szabadidős céllal. A fajlagos üzemanyag-felhasználást tekintve szintén ellentmondásos a kép, a magasabb jövedelmú budapestieknek egyrészt több lehetőségük van energiatakarékosabb, alacsonyabb fogyasztású személygépkocsik vásárlására, másrészt előfordulhat a nagy presztízsủ és hengerűrtartalmú, nagyobb fogyasztású személygépkocsik vásárlása is, így ezen a területen nem lehet egyértelmú tendenciát azonosítani.

A közvetlen lakossági lábnyomnál az egy fớre jutó értékek részletesebb elemzésével több információhoz jutunk, az abszolút értékek tekintetében (Budapesten 2003-ban 582088 gha, 2013-ban 547777 gha, az agglomerációban 2003-ban 574572 gha, 2013-ban 744288 gha) a mintaterületek eltérő népességszáma és annak változása játszik szerepet.

Területi Statisztika, 2019, 59(1): 97-123; DOI: 10.15196/TS590105 
A lakossági közvetlen beépített területlábnyomot (lakóingatlanok területe, illetve az úthálózat lakossági használatot szolgáló része) nem tudtuk számszerúsíteni, így becslésünk a teljes ökológiai lábnyom szempontjából alsó becslésnek tekinthető.

\section{A közvetlen és közvetett budapesti és agglomerációs lakossági ökológiai lábnyom értékelése}

A budapesti várostérség összesített (közvetett - a fogyasztási javakba beépülő - és közvetlen) lakossági ökológiai lábnyomának számítása alapján megállapítható, hogy 2003 és 2013 között mindkét vizsgált területen nőtt az összesített ökológiai lábnyom. A korábbiakkal összhangban, míg Budapesten az emelkedés elsősorban a növekvő egy főre jutó fogyasztásnak, másodsorban a népességnövekedésnek köszönhető, addig az agglomerációban elsősorban a népességnövekedés a meghatározó, de kimutatható a közvetlen fütési lábnyom növekedése is a szilárd tüzelőanyagok arányának emelkedésével összefüggésben.

Az ökológiailábnyom-értékeket a vizsgált területek biokapacitásával ${ }^{2}$ összevetve kapjuk meg, hogy előbbiek mennyiben tekinthetők fenntarthatónak (5. táblázat).

5. táblázat

\section{A lakossági fogyasztás összesített ökológiai lábnyoma és a biokapacitás viszonya Budapesten, az agglomerációban, illetve Magyarországon}

Relation between total ecological footprint of household consumption and

biocapacity in Budapest, its agglomeration, and Hungary, in 2003 and 2013

\begin{tabular}{|c|c|c|c|c|c|c|c|}
\hline \multirow{3}{*}{ Megnevezés } & \multirow{2}{*}{\multicolumn{2}{|c|}{ Ökológiai lábnyomaa) }} & \multirow{2}{*}{\multicolumn{2}{|c|}{ Biokapacitás $\left.{ }^{b}\right)$}} & \multirow{3}{*}{ Terület } & \multirow{2}{*}{\multicolumn{2}{|c|}{ Ökológiai túllövésc) }} \\
\hline & & & & & & & \\
\hline & 2003 & 2013 & 2003 & 2013 & & 2003 & 2013 \\
\hline Budapest & 4216 & 4395 & 115 & 136 & 52,5 & 36,64 & 32,37 \\
\hline Agglomeráció & 2873 & 3224 & 1216 & 1435 & 555,2 & 2,36 & 2,25 \\
\hline Magyarország & 24369 & 22605 & 20381 & 24054 & 9303,0 & 1,20 & 0,94 \\
\hline Magyarország - teljes & 38463 & 32498 & 20381 & 24054 & 9303,0 & 1,89 & 1,35 \\
\hline
\end{tabular}

Megjegyzés: Az országos teljes ökológiai lábnyom és biokapacitás forrása a GFN-adatbázis, a többi saját számítás.

a) Az ökológiailábnyom-értékek a lakossági fogyasztásra vonatkoznak (közvetett és közvetlen együtt), kivéve a „Magyarország - teljes” sort, ami a teljes nemzeti végső fogyasztásra vonatkozik (beleértve az állami/kormányzati és a harmadik szektort, de az export nélkül).

b) A budapesti és az agglomerációs biokapacitást az országosból, a fizikai területek arányában számítottuk ki.

c) Ökológiai túllövés állapota akkor áll elő, amikor az emberi igények meghaladják a természetes ökoszisztémák regeneratív kapacitásait. A globális, azaz a bolygó szintű túllövés akkor áll elő, amikor az emberiség erőforrás igényei és hulladéktermelése (mint amilyen bizonyos értelemben a szén-dioxid-kibocsátás is) meghaladja a bioszféra regeneratív és abszorpciós kapacitásait.

${ }^{2}$ Biokapacitás: (biológiai kapacitás) az ökoszisztémák azon képességének mértéke, hogy hasznos biológiai anyagokat állítsanak elő és hogy abszorbeálják a hulladékokat az emberi tevékenységekbool az aktuálisan alkalmazott technológiai színvonal mellett.

Területi Statisztika, 2019, 59(1): 97-123; DOI: 10.15196/TS590105 
Az összesített (közvetett és közvetlen) lakossági ökológiai lábnyomot bemutató 5. táblázat alapján látható, hogy Budapest és az agglomeráció lakossági fogyasztásának ökológiai lábnyoma nőtt 2003 és 2013 között, illetve jelentősen meghaladja a területek biokapacitását. Dinamikus megközelítésben a fenntarthatatlanság állapotát jelzi, ha az ökológiai lábnyom meghaladja az adott terület biokapacitását, ezt nevezzük túllövésnek (angolul overshoot, Costanza 2000). Világszinten évente kiszámolják, hogy az év mely részére „használja el” az emberiség az adott évre elérhető biokapacitást, ez 2018-ban augusztus 1-jén következett be (Earth Overshoot Day 2018).

Az eredmények alapján látható, hogy Budapesten 37-, illetve 32-szeres a túllövés, azaz ennyiszerese a számított ökológiai lábnyom a teljes biokapacitáshoz viszonyítva. Ez sokkal nagyobb az egyetlen rendelkezésre álló magyarországi referenciaértéknél, Győrben Szigeti (2010) számításai szerint 2010-re 17-szeres volt a túllövés. Az eltérést indokolhatja, hogy a jelenlegi számítás a módszertan jellegéből adódóan az ökológiai lábnyomot szélesebb körben értelmezi, illetve mutathatja azt is, hogy Budapesten területileg még inkább koncentrálódik az ökológiai lábnyom. Az agglomerációban is jelentős a túllövés, 2003-ban 2,4-szeres, míg 2013-ban 2,2-szeres volt (ha a teljes biokapacitás értékei helyett a mintaterületek földrajzi kiterjedésére vetítenénk az ökológiailábnyom-értékeket, akkor a túllövés mindkét mintaterületnél még ennél is nagyobb lenne ${ }^{3}$ ). Jelentôs a lakossági ökológiai lábnyom alulbecslése továbbá, hogy a közvetlen beépített területet (lakóingatlanok, illetve az úthálózat lakossági fogyasztásra jutó része) nem tudtuk számszerúsíteni, holott ezek kiterjedése a budapesti várostérségben az országos átlaghoz képest sokkal jelentősebb. Az eredmények értelmezéséhez kapcsolódik, hogy az 5. táblázatban a Budapest és az agglomeráció biokapacitását úgy számoltuk ki, hogy a GFN-adatbázisból származó értéket arányosítottuk a mintaterületek földrajzi kiterjedése alapján. Ezzel közvetve azt feltételeztük, hogy a budapesti és az agglomerációs területek biológiai produktivitása az országos átlaggal megegyezik.

Tanulmányunkban csak a lakossági fogyasztás lábnyomát számoltuk, ami nem tartalmazta az állami/kormányzati tevékenység (amely szintén budapesti központú), a harmadik szektor, illetve az export ökológiai lábnyomát. Emiatt lehetséges, hogy az 5. táblázat harmadik sorában, a magyarországi ökológiai lábnyom esetében nincs (jelentős) túllövés. Ezzel szemben, ha a negyedik sorban szereplő teljes, azaz nem csak a lakossági fogyasztást tartalmazó lábnyomot vesszük figyelembe, akkor látható, hogy a túllövés országos szinten is jelentôs, hiszen az ökológiai lábnyom 2003-ban 90, 2013-ban 40\%-kal haladta meg a biokapacitást.

3 Az eltérés a globális hektár és a „hagyományos” hektárban mért értékek között azzal magyarázható, hogy az ökológiai lábnyom és a biokapacitás számszerűsítése során egyrészt figyelembe vesszük az egyes országok közötti eltérô hozamokat (a hozamfaktor, YF segítségével), másrészt azt is, hogy a különböző területtípusok (szántó, legelő, erdő stb.) eltérőek a biológiai produktivitásuk tekintetében (ezt pontosítja az ekvivalencia faktor, EQF). Ezek módszertani hátterérôl lásd bővebben Csutora (2011) munkáját.

Területi Statisztika, 2019, 59(1): 97-123; DOI: 10.15196/TS590105 
Egyfelől a túllövés mértéke mindhárom szinten (Budapest, agglomeráció, ország) csökkent 2003 és 2013 között. Budapesten és az agglomerációban nőtt az ökológiai lábnyom (szemben az országos érték csökkenésével), ennél azonban jelentősebb a biokapacitás bővülése. Ez a GFN-módszertana alapján azzal magyarázható, hogy 2013-ban a kedvezőbb időjárás és a technológiai fejlődés eredményeként emelkedett az ország biológiai produktivitása. Ugyanakkor ez a kedvező irányú változás sem volt elegendő a fenntarthatóság eléréséhez.

Másfelől ugyanakkor természetes, hogy egy fővárosban, illetve agglomerációjában koncentrálódik az ország népességének és gazdaságának jelentős része, amely a magas ökológiai lábnyomért „cserében” gazdasági hozzáadott értéket és egyéb szolgáltatásokat kínál az ország többi részének. Kérdés, hogy az óriási ökológiai lábnyomra fedezetet nyújt-e az ország fennmaradó része. Mindezt az egy főre jutó ökológiai lábnyom, illetve az országos, valamint a globális biokapacitás adataival vizsgáltuk (6. táblázat).

6. táblázat

A lakossági fogyasztás egy főre jutó ökológiai lábnyomának fenntarthatósági szempontú értékelése Budapesten, az agglomerációban, illetve Magyarországon

Sustainability assessment of per capita ecological footprint of household consumption in Budapest, its agglomeration, and Hungary for 2003 and 2013

\begin{tabular}{|c|c|c|c|c|c|c|c|c|c|c|}
\hline \multirow{3}{*}{ Megnevezésa) } & \multirow{2}{*}{\multicolumn{2}{|c|}{$\begin{array}{l}\text { Ökológiai } \\
\text { lábnyom }\end{array}$}} & \multicolumn{4}{|c|}{ Biokapacitás } & \multicolumn{4}{|c|}{ Ökológiai túllövés } \\
\hline & & & \multicolumn{2}{|c|}{ országos } & \multicolumn{2}{|c|}{ globális } & \multicolumn{2}{|c|}{ országos } & \multicolumn{2}{|c|}{ globális } \\
\hline & 2003 & 2013 & 2003 & 2013 & 2003 & 2013 & 2003 & 2013 & 2003 & 2013 \\
\hline Budapest & 2,47 & 2,52 & \multirow{4}{*}{2,01} & \multirow{4}{*}{2,42} & \multirow{4}{*}{1,81} & \multirow{4}{*}{1,69} & 1,23 & 1,04 & 1,37 & 1,49 \\
\hline Agglomeráció & 2,73 & 2,79 & & & & & 1,36 & 1,15 & 1,51 & 1,65 \\
\hline Magyarország & 2,40 & 2,26 & & & & & 1,20 & 0,94 & 1,33 & 1,34 \\
\hline Magyarország - teljes & 3,79 & 3,27 & & & & & 1,89 & 1,35 & 2,09 & 1,93 \\
\hline
\end{tabular}

Megjegyzés: Az országos teljes ökológiai lábnyom és a biokapacitás adatainak forrása a GFN-adatbázis, a többi érték saját számítás eredménye.

a) Az ökológiailábnyom-értékek a lakossági fogyasztásra vonatkoznak (közvetett és közvetlen együtt), kivéve a „Magyarország - teljes” sort, ami a teljes nemzeti végső fogyasztásra vonatkozik (beleértve az állami/kormányzati és a harmadik szektort, de az export nélkül).

Az egy főre jutó ökológiai lábnyom adatainak vizsgálatából megállapítható, hogy az agglomerációs érték körülbelül 10\%-kal magasabb, mint a budapesti, illetve mindkettő kismértékben (2-2,1\%-kal) nőtt 2003 és 2013 között. A magasabb agglomerációs érték hátterében elsősorban a magasabb közvetlen lábnyom (főlleg a fütési karbonlábnyom) áll, illetve az agglomerációs érték időbeli növekedését is ez a tényező magyarázza (ebben kiemelt szerepe van a fatüzelés újbóli elterjedésének).

Területi Statisztika, 2019, 59(1): 97-123; DOI: 10.15196/TS590105 
Budapesten időben csökkent a közvetlen ökológiai lábnyom értéke, a növekedést a nagyobb jólét és a magasabb egy főre jutó fogyasztás magyarázza.

Ha a lakossági ökológiai lábnyom értékeket a magyarországi és globális biokapacitás adatokhoz viszonyítjuk, egyértelmű a válasz a korábbi kérdésre, hogy vajon a fővárosi agglomeráció lakosságának életvitele fenntartható-e tágabb összefüggésben. A 6. táblázat alapján látható, hogy ha Magyarországon, illetve a világon mindenki úgy élne, mint egy átlagos budapesti, vagy agglomerációs lakos, akkor jóval több erőforrásra lenne szükségünk, mint amennyi hosszú távon biztositható ${ }^{4}$. Természetesen itt is hozzá kell tenni, hogy a lábnyomértékek a táblázat első három adatsorában csak a lakossági fogyasztásra vonatkoznak, míg a biokapacitás esetében nincs ilyen arányosítás. A magyarországi teljes adatokat tekintve (negyedik adatsor) azonban látszik, hogy a lakossági fogyasztáson kívüli lábnyomösszetevőket is vizsgálva a túllövés még markánsabb.

\section{Összegzés}

A világ várostérségeire az elmúlt néhány évtizedben általánosan jellemző volt a szétterülés, az urban sprawl folyamata. Ez a dinamikusan növekvő népességü (Afrika, Ázsia) és a zsugorodó térségekben (Európa) egyaránt jellemző. Ez ráirányítja a kutatók figyelmét az urbanizáció környezeti fenntarthatóságára. Tanulmányunkban Budapest és az agglomeráció fejlődésének környezeti hatásait vizsgáltuk, az ökológiai lábnyom koncepciójának segítségével. A számítások során nemcsak a közvetlen, hanem a lakossági fogyasztásba beépülő közvetett ökológiai lábnyomot is kiszámoltuk a környezetvédelmi adatokkal kiegészített ÁKM segítségével.

A legfontosabb eredményeink a következők:

- A lakossági fogyasztásba beépüló ökológiai lábnyom eltérő irányú változást mutatott a különböző területi egységek szintjén 2003 és 2013 között. Míg országosan 11\%-kal csökkent, addig Budapesten 6, az agglomerációban 8\%-kal nőtt.

- A változást egyrészt a népességszám-változás eltérő dinamikája, másrészt az egy főre jutó fogyasztás nagyságának és szerkezetének alakulása magyarázza. Budapesten a növekedést az egyéni fogyasztás bővülése, az agglomerációban a népességszám emelkedése okozta.

- Az eltérô társadalmi környezetből és a fogyasztási szerkezetből adódóan 2013-ban az agglomerációban az élelmiszer-fogyasztás, az energiafogyasztás és a közlekedés egy főre jutó beépülő ökológiai lábnyoma nagyobb volt, mint Budapesten. A fővárosban viszont magasabb volt az egészségügyhöz, az oktatáshoz, a ruházkodáshoz és a szolgáltatásokhoz (telekommunikáció, szóra-

${ }^{4}$ A korábbiakkal összhangban a biokapacitás időbeli változása egyrészt a népesedési változásoknak (a növekvő globális népesség miatt csökkent az egy főre jutó globális biokapacitás, de a magyarországi kismértékben nőtt), másrészt egyéb, például klimatikus, technológiai tényezőkkel (a jobb terméshozam következtében nőtt az egy főre jutó gha-ban kifejezett növénytermesztési terület Magyarországon) magyarázható.

Területi Statisztika, 2019, 59(1): 97-123; DOI: 10.15196/TS590105 
kozás és kultúra, vendéglátás és szálláshelyi szolgáltatások) kapcsolódó lábnyom értéke. Ez utóbbiak leginkább a nagyobb egy főre jutó jövedelemből adódó magasabb fogyasztási lehetóségekkel magyarázhatók.

- A közvetlen lakossági egy főre jutó ökológiai (karbon-) lábnyom az agglomerációban sokkal nagyobb (2013-ban több mint kétszerese), mint Budapesten. A fútés és a közlekedés közvetlen lábnyoma közül az előbbi a jelentősebb, illetve az agglomerációs magasabb érték elsősorban a nagyobb közvetlen fütési lábnyommal magyarázható. A jármúüzemanyag közvetlen karbonlábnyomában nincs jelentős eltérés a két terület között (körülbelül 10\%-kal magasabb az egy főre jutó agglomerációs lábnyom).

- Az összesített (közvetett és közvetlen) lakossági ökológiai lábnyom Budapesten rendkívüli, 2003-ban 37-, 2013-ban 32-szeres a túllövés, azaz ennyi szerese a számított ökológiai lábnyom a teljes területhez viszonyítva. Ez az érték az agglomerációban 2003-ban 2,4-szeres, míg 2013-ban 2,2-szeres volt. A csökkenő tendencia azzal magyarázható, hogy a viszonyítási alapként szolgáló biokapacitás értéke időjárási, illetve technológiai okok miatt nőtt 2003 és 2013 között, de még így is nagyon jelentős a túllövés.

- Az egy főre jutó ökológiai lábnyomból az alulbecslés ellenére is megállapítható, hogy egy átlagos budapesti és egy agglomerációs lakos (csak lakossági fogyasztást tartalmazó) ökológiai lábnyoma is jelentősen (a két mintaterület, illetve a két időszak szélsőértékeit tekintve 4-65\%-kal) meghaladja az egy főre jutó magyarországi, illetve globális biokapacitást, így a jelenlegi életvitel ezeken a mintaterületeken nem tekinthető fenntarthatónak.

Az eredmények alapján bizonyos következtetések levonhatók arra vonatkozóan is, hogy a budapesti várostérség népességének és területi kiterjedésének növekedése, a szuburbanizáció, illetve a kívülről történő bevándorlás milyen hatást gyakorolt az ökológiai lábnyomra és annak belső szerkezetére a vizsgált időszakban. Látható, hogy míg mind Budapest, mind az agglomeráció lakossági ökológiai lábnyoma hasonló ütemben növekedett, addig az országos lábnyom csökkent. A várostérség központjánál (Budapest) az ökológiai lábnyom növekedéséért elsősorban az egy főre jutó magas jövedelem és a folyamatosan bővülő lakossági fogyasztás (közvetett ökológiai lábnyom növekedése) a felelős. Budapesten 2003 és 2013 között az egy főre jutó bruttó hazai termék folyamatosan, több mint kétszeresen meghaladta az országos átlagot, különösen nagy volt az olló a 2008-as gazdasági világválság körüli és az utáni években. Míg az ország többi része megsínylette a válságot, addig Budapesten nem esett vissza a gazdaság, stabil maradt, majd nőtt a fogyasztás is, és az ebből származó ökológiai lábnyom 4\%-kal emelkedett. Az agglomerációban a lakossági fogyasztás egy fớre jutó ökológiai lábnyoma $2 \%$-kal csökkent, viszont nagyon gyorsan emelkedett a fútésből származó közvetlen karbonlábnyom.

Az adatok azt is igazolták, hogy az agglomerációba nem csak jómódú családok költöznek Budapestről, hanem továbbra is számottevő az elsősorban vidékről történő, alacsonyabb státusú népesség beköltözése. A vizsgált, válsággal is terhelt idô-

Területi Statisztika, 2019, 59(1): 97-123; DOI: 10.15196/TS590105 
szakban Budapest ökológiai lábnyomának növekedésével párhuzamosan ugyanolyan arányban nőtt az agglomeráció ökológiai lábnyoma is, de más-más ok áll a háttérben: míg Budapesten a fogyasztás, addig az agglomerációban az energiafelhasználás növekedése a fő tényező. Mindez arra a törvényszerűségre emlékeztet, amely szerint a várostérség szétterülésének folyamatában növekszik a központ lakossági ökológiai lábnyoma is, mivel folyamatosan fejlődik a gazdaság, ez pedig közrejátszik a periféria ökológiai lábnyomának növekedésében, mivel erősíti az elsősorban közvetlen kibocsátást függetlenül attól, hogy teljesen monocentrikus, vagy részben policentrikus egy várostérség. Hazai sajátosságnak tekinthető, hogy a vizsgált időszakban a periféria közvetlen lábnyomának növekedése elsősorban nem az ingázás révén emelkedő üzemanyag-fogyasztásnak, hanem a fútésnek a következménye. Ennek hátterében részben az állhat, hogy a jelen tanulmányban lehatárolt ingázási zóna messze túlnyúlik a kedvezőbb jövedelmi mutatókkal rendelkező Budapesttel közvetlenül határos települések körén, egyben utal a periférián élő alacsonyabb jövedelmú népesség nagyobb arányára, a gyenge energiahatékonyságra is. Budapest nagy területi kiterjedése, a közigazgatási határokon belüli jelentős személygépkocsi-használat állhat annak hátterében, hogy a járművek üzemanyag-fogyasztásának közvetlen ökológiai lábnyoma a két térségtípusban lényegében megegyezik.

A tanulmány alapján megállapítható, hogy az ökológiai lábnyom módszertana alkalmas a lakossági fogyasztás környezeti szempontú értékelésére nemcsak a közvetlen, hanem a közvetett (máshol jelentkező) összetevők tekintetében is. Szintén alkalmas bármilyen földrajzi egység vizsgálatára, ennek feltétele, hogy a fogyasztási adatok az adott területre megfelelő bontásban álljanak rendelkezésre. Ezen túlmenően, a módszer a jövőben felhasználható lehet egy-egy részterület (például ingázás) mélyebb vizsgálatára is, ennek azonban szintén feltétele, hogy az adott tevékenységre fordított kiadásokkal kapcsolatban megfeleló adatokkal rendelkezzünk az adott területre vonatkozóan.

\section{Köszönetnyilvánítás}

A tanulmány az Országos Tudományos Kutatási Alapprogramok (OTKA) K119710 számú kutatási és a Nemzeti Versenyképességi és Kiválósági Program (NVKP) 16-1-2016-0003 számú projektjének támogatásával készült.

\section{IRODALOM}

Ala-Mantila, S.-Heinonen, J.-Junnila, S. (2013): Greenhouse Gas Implications of Urban Sprawl in the Helsinki Metropolitan Area Sustainability 5 (10): 4461-4478. https://doi.org/10.3390/su5104461

Barrett, J.-Birch, R.-ChERrett, N.-Wiedmann, T. (2005): Reducing Wales' Ecological Footprint-Main Report Stockholm Environment Institute, University of York, WWF Cymru, Cardiff, UK.

Területi Statisztika, 2019, 59(1): 97-123; DOI: 10.15196/TS590105 
Bicknell, K. B.-BALl, R. J.-Cullen, R.-Bigsby, H. R. (1998): New methodology for the ecological footprint with an application to the New Zealand economy Ecological Economics 27 (2): 149-160. https://doi.org/10.1016/S0921-8009(97)00136-5

BOHNET, I.C.-PERT, P. L. (2010): Patterns, drivers and impacts of urban growth-A study from Cairns, Queensland, Australia from 1952 to 2031 Landscape and Urban Planning 97 (4): 239-248. https://doi.org/10.1016/j.landurbplan.2010.06.007

Burgalassi, D.-LuZZATI, T. (2015): Urban SPATIAL structure and environmental emissions: A survey of the literature and some empirical evidence for Italian NUTS 3 regions Cities 49: 134-148. https://doi.org/10.1016/j.cities.2015.07.008

COLLINS, A.-FLYNN, A.-WIEDMANN, T.-BARRETT, J. (2006): The environmental impacts of consumption at a subnational level Journal of Industrial Ecology 10 (3): 9-24. https://doi.org/10.1162/jiec.2006.10.3.9

COSTANZA, R. (2000): The dynamics of the ecological footprint concept Ecological Economics 32 (3): 341-345. https://doi.org/10.1016/S0921-8009(99)00150-0

CuCEK, L.-KLEMES, J. J.-KRAVANJA, Z. (2012): A Review of Footprint analysis tools for monitoring impacts on sustainability Journal of Cleaner Production 34: 9-20. https://doi.org/10.1016/j.jclepro.2012.02.036

CsutorA, M. (2011): Az ökológiai lábnyom számításának módszertani alapjai. In: CsuTORA, M. (szerk.): Az ökológiai lábnyom ökonómiája: Tematikus kötet pp. 6-15., Aula Kiadó, Budapest.

Csutora, M.-TABI, A.-Vetőné MóZner, Zs. (2011): A magyar háztartások ökológiai lábnyomának vizsgálata In: CSUTORA, M. (szerk.): Az ökológiai lábnyom ökonómiája: Tematikus kötet pp. 27-38., Aula Kiadó, Budapest.

Dobos, I.-CSuTORA, M. (2010): The calculation of dynamic ecological footprint on the basis of the dynamic input-output model Working paper, Corvinus University of Budapest, Budapest.

DÖVÉNYI, Z. (2007): A belföldi vándormozgalom strukturális és területi sajátosságai Magyarországon Demográfia 50 (4): 335-359.

DÖVÉNYI, Z. (2009): A belső vándormozgalom Magyarországon: folyamatok és struktúrák Statisz̨tikai Szemle 87 (7-8): 748-762.

DÖVÉNYI, Z.-KOVÁCS, Z. (1999): A szuburbanizáció térbeni-társadalmi jellemzői Budapest környékén Földrajzi Értesitô" 48 (1-2): 33-57.

ENYEDI, GY. (2010): Az urbanizációs ciklus és a magyar településhálózat átalakulása In: Barta, Gy.-Beluszky, P.-FÖLDI, Zs.-KovÁcs, K. (szerk.) A területi kutatások csomópontjai pp. 107-120. MTA Regionális Kutatások Központja, Pécs.

FANG, K.-ZHANG, Q.-YU, H.-WANG, Y.-DONG, L.-SHI, L. (2018): Sustainability of the use of natural capital in a city: Measuring the size and depth of urban ecological and water footprints Science of the Total Environment (631-632): 476-484. https://doi.org/10.1016/j.scitotenv.2018.02.299

FÁBIÁN, Z.-KOLOSI, T.-RÓBERT, P. (2008): Fogyasz̨ási csoportok TÁRKI Társadalompolitikai Tanulmányok 20., Budapest.

FERNG, J. J. (2001): Using composition of land multiplier to estimate ecological footprints associated with production activity Ecological Economics 37 (2): 159-172. https://doi.org/10.1016/S0921-8009(00)00292-5

Területi Statisztika, 2019, 59(1): 97-123; DOI: 10.15196/TS590105 
Gu, Q.-WAng, H.-ZhenG, Y.-Zhu, J.-LI, X. (2015): Ecological footprint analysis for urban agglomeration sustainability in the middle stream of the Yangtze River Ecological Modelling 318: 86-99. https://doi.org/10.1016/j.ecolmodel.2015.07.022

HARANGOZÓ, G.-SzÉCHY, A. Zs.-ZilahY, GY. (2016): A fenntarthatósági lábnyommegközelítések szerepe a vállalatok fenntarthatósági szempontú teljesítményértékelésében Vezetéstudomány 47 (7): 2-13.

Heinonen, J.-Kyrö, R.-JunNilA, S. (2011): Dense downtown living more carbon intense due to higher consumption: a case study of Helsinki Environmental Research Letters 6 (3): 1-9.

HEINONEN, J.-JUNILLA, S. (2011): Implications of urban structure on carbon consumption in metropolitan areas Environmental Research Letters 6 (1): 1-9.

HIRT, S. (2007): Suburbanizing Sofia: Characteristics of post-socialist peri-urban change Urban Geography 28 (8): 755-780. https://doi.org/10.2747/02723638.28.8.755

Jones, Ch.-Kammen, D. M. (2014): Spatial Distribution of U.S. Household Carbon Footprints Reveals Suburbanization Undermines Greenhouse Gas Benefits of Urban Population Density Environmental Science and Technology 48 (2): 895-902. https://doi.org/10.1021/es4034364

KISS, T.-GirÁN, J. (2004): Verseny helyett kooperáció. Pécs ÖKOVÁROS — MecsekDráva ÖKORÉGIÓ program bemutatása Tér és Társadalom 18 (4): 85-94.

KONDOR, A. (2016): Helyi konfliktusok Budapest szuburbán zónájában Földrajzi Közlemények 140 (3): 216-228.

KONDOR, A. Cs.-KOVÁCs, Z. (2017): Kibocsátáscsökkentés és urbanizáció: ellentmondások és párhuzamok Magyar Tudomány 178 (6): 686-690.

KovÁcs, Z. (2017): Városok és urbanizációs kihívások Magyarországon Magyar Tudomány 178 (3): 302-310.

KovÁcs, Z.-EgEDy, T. (2016): Budapest a városfejlesztési politika útvesztőjében: a metropolizáció rögös útjai In: SIKOS, T. T.-TINER, T. (szerk.): Tájak, régiók, települések térben és idóben: tanulmánykötet Beluszky Pál 80. születésnapjára pp. 219-230. Dialóg Campus Kiadó, Budapest.

KovÁcs, Z.-Szigeti, C.-Egedy, T.-SzABÓ, B.-Kondor, A. Cs. (2017): Az urbanizáció környezeti hatásai - az ingázás ökológiai lábnyomának változása a budapesti várostérségben Területi Statisztika 57 (5): 469-494.

KovÁCs, Z.-TosiCs, I. (2014): Urban sprawl on the Danube: the impacts of suburbanization in Budapest In: STANILOV, K.-SÝKORA, L. (Eds.) Confronting suburbanization: Urban decentralization in postsocialist Central and Eastern Europe pp. 33-64., WileyBlackwell, Oxford.

KSH (2012a): Magyarország, 2011, Budapest.

KSH (2012b): A belföldi vándorlás főbb folyamatai, 1990-2011 Statisqtikai Tükör 6 (85): 1-5.

LeetmaA, K.-TAmmaru, T.-Anniste, K. (2009): From priority-led to market-led suburbanization in a post-communist metropolis Tijdschrift voor Economische an Sociale Geografie 100 (4): 436-453. https://doi.org/10.1111/j.14679663.2009.00551.x

Területi Statisztika, 2019, 59(1): 97-123; DOI: 10.15196/TS590105 
LEONTIEF, W. (1936): Quantitative input and output relations in the economic system of the United States Review of Economics and Statistics 18 (3): 105-125. https://doi.org/10.2307/1927837

LU, Y.-CHEN, B. (2017): Urban ecological footprint prediction based on the Markov chain Journal of Cleaner Production 163: 146-153. https://doi.org/10.1016/j.jclepro.2016.03.034

MuñIZ, I.-GALINDO, A. (2005): Urban form and the ecological footprint of commuting. The case of Barcelona Ecological Economics 55 (4): 499-514. https://doi.org/10.1016/j.ecolecon.2004.12.008

MuÑIZ, I.-SÁNCHEZ, V. (2018): Urban Spatial Form and Structure and Greenhouse-gas Emissions From Commuting in the Metropolitan Zone of Mexico Valley Ecological Economics 147: 353-364 https://doi.org/10.1016/j.ecolecon.2018.01.035

OUŘEDNíČEK, M. (2007): Differential suburban development in the Prague urban region Geografiska Annaler, Series B: Human Geography 89 (2): 111-126.

Peters, G. P.-Hertwich, E. G. (2008): $\mathrm{CO}_{2}$ embodied in international trade with implications for global climate policy Environmental Science and Technology 42 (5): 1401-1407. https://doi.org/10.1021/es072023k

Pichler-Milanović, N. (2014): Confronting Suburbanization in Ljubljana: From "Urbanization of the Countryside" to Urban Sprawl In: STANILOV, K.-SÝKORA, L. (Eds.), Confronting suburbanization: Urban decentralization in postsocialist Central and Eastern Europe pp. 65-96., Wiley-Blackwell, Oxford.

PiÑA, W. H. A.-MARTinEZ, C. I. P. (2014): Urban material flow analysis: An approach for Bogotá, Colombia Ecological Indicators 42: 32-42. https://doi.org/10.1016/j.ecolind.2013.10.035

Rashid, A.-Irum, A.-Ali Malik, I.-Ashraf, A.-Rongliong, L.-LiU, G. - Ullah, H. ALI, M. U.-YousAF, B. (2018): Ecological footprint of Rawalpindi; Pakistan's first footprint analysis from urbanization perspective Journal of Cleaner Production 170 (1): 362-368. https://doi.org/10.1016/j.jclepro.2017.09.186

REES, W. E. (1992): Ecological footprints and appropriated carrying capacity: What urban economics leave out Environment and Urbanization 4 (2): 121-130. https://doi.org/10.1177/2455747117699722

STANILOV, K.-SÝKORA, L. (Eds.) (2014): Confronting suburbanization: urban decentralization in postsocialist Central and Eastern Europe Wiley-Blackwell, Oxford.

SCHMidT, S.-FINA, S.-Siedentop, S. (2015): Post-socialist sprawl: A cross-country comparison European Planning Studies 23 (7): 1357-1380. https://doi.org/10.1080/09654313.2014.933178

Simmons, C.-LEWIS K.-BARRETT, J. (2000): Two feet - two approaches: a componentbased model of ecological footprinting Ecological Economics 32 (3): 375-380.

SZABÓ, T.-SZABÓ, B.-KovÁCS, Z. (2014): Polycentric urban development in post-socialist context: the case of the Budapest Metropolitan Region Hungarian Geographical BulLetin 63 (3), 287-301. https://doi.org/10.15201/hungeobull.63.3.4

SzIGETI, C. (2010): Gyốr ökológiai lábnyoma Fenntarthatósági Füzetek, CG Kutató és Tanácsadó Kft., Győr.

Területi Statisztika, 2019, 59(1): 97-123; DOI: 10.15196/TS590105 
VÁClavík, T.-Rogan, J. (2009): Identifying Trends in Land Use/Land Cover Changes in the Context of Post-Socialist Transformation in Central Europe: A Case Study of the Greater Olomouc Region, Czech Republic GIScience \& Remote Sensing 46 (1): 54-76. https://doi.org/10.2747/1548-1603.46.1.54

VETŐNÉ MÓZNER, Zs. (2012): A fogyasztási szemlélet jelentősége a természeti erőforrások és a $\mathrm{CO}_{2}$-kibocsátások elszámolásában Fenntartható Életmód Mühelytanulmányok 1: $1-31$.

WACKeRnAGEL, M.-REes, W. E. (1996): Our ecological footprint: Reducing human impact on the Earth New Society Publishers, Gabriola Island, BC.

Wiedmann, T.-Minx, J.-BARRETT, J.-WACKERnAGEL, M. (2006): Allocating ecological footprints to final consumption categories with input-output analysis Ecological Economics 56 (1): 28-48. https://doi.org/10.1016/j.ecolecon.2005.05.012

\section{INTERNETES HIVATKOZÁSOK}

EARTH OVERSHOOT DAY (2018): https://www.overshootday.org/ (letöltve: 2018.06.10.)

ENSZ (2011): Classification of Individual Consumption According to Purpose (COICOP). https://unstats.un.org/unsd/iiss/Classification-of-Individual-ConsumptionAccording-to-Purpose-COICOP.ashx (letöltve: 2018.05.13.)

GFN (2012): Footprint Basics - Overview Global Footprint Network www.footprintnetwork.org. (letöltve 2018.05.19.)

GFN (é.n.): Global Footprint Network, Open Data Platform http://data.footprintnetwork.org/\#/ (letöltés: 2018.06.15.)

$\mathrm{KSH}$ (é.n.): A fogyasztói fö́csoportok (COICOP) rövid bemutatása http://www.ksh.hu/docs/hun/xftp/stattukor/haztfogy/haztfogyhavi1306m.pdf (letöltve: 2018.05.13.)

Területi Statisztika, 2019, 59(1): 97-123; DOI: 10.15196/TS590105 